\title{
reprints
}

Hypothesis

\section{Investors Perception Towards Investment With Reference To Modern And Other Traditional Tools}

\author{
Bhavesh Kumar Rathod 1,*, V Asha ${ }^{2}$ and J Gajendra Naidu ${ }^{2}$ \\ \#296, 5th A Main, 2nd Cross , Kengeri Satellite Town, Bangalore 560060 , India \\ \#17-41, 2nd A Main, Ittamadu, BSK - 3rd Stage, Bangalore 560085, India \\ * Correspondence: bhavesh_mncl@yahoo.com; Tel.: +919535252807
}

\begin{abstract}
There are many modern and traditional methods in valuing the performance of the company among them EVA, CVA are modern methods where as EPS, ROI, ROE etc. are some of the traditional methods. modern and traditional methods are not only used to check the performance of a company but it also used in investment decisions by the investors. Stern Stewart, managing partner of M/s Stern Stewart \& Co. introduced a modified concept of economic profit in 1990 in the name of Economic Value Added (EVA) as measure of business performance and CVA is only a cash consideration in EVA. In this paper an attempt is made to study which method is used by the investors while taking the investment decisions i.e. traditional methods are modern methods. 100 respondents (Investors) are questioned and collected their views, we are assuming that there is no impact of traditional or modern methods while taking investment decisions by the investors.
\end{abstract}

Keywords: EVA, EPS, CVA, Respondent

\section{Introduction}

A company's real economic profit or EVA is the amount it earns in excess of the cost of capital where as CVA(Cash Value Added), It includes only cash items, i.e. Earnings Before Depreciation Interest and Tax (EBDIT, adjusted for non-cash charges), working capital movement and non-strategic investments. An enterprise creates wealth for its shareholders only when there are profits left after meeting a charge on the capital employed by the company. There is evidence that suggests that companies that have focused on earning a return on capital in excess of the cost of capital have been the most successful in consistently increasing shareholder wealth and also builds confidence in investors to invest And companies that deliver shareholder returns are able to access lower cost funds thereby entering a beneficial cycle as opposed to a vicious cycle. As firms increasingly rely on the capital markets for funds, those that have provided good returns to their investors would be at an advantage in raising further resources at advantageous terms. Since the primary objective of commercial organizations is normally assumed to be the maximization of the wealth of its shareholders. In practice, many organizations use profit-based measures as the primary measure of their financial performance and as investors most of the time uses profit as a base to invest. Two problems relating to investment in this regard are:

- Profit ignores the cost of equity capital. Companies only generate wealth when they generate a return in excess of the return required by providers of capital - both equity and debt. In financial statements, the calculation of profit does take into account the cost of debt finance, but ignores the cost of equity finance.

- Traditional methods like EPS, ROI, ROC etc uses profit and ignores cost which is one of the most important component in evaluating the performance of an organization. 
- Investment decision taken by investors based on traditional methods which does not consider cost of capital may not be useful now a days

\section{REVIEW OF LITERATURE}

In last 15 years many articles dealing with theory and application of EVA has been published out of which one article by Ms. Anitha , D. Phani Bhargavi(2010) titled "Investors' Perception Towards Investment" different demographic variables are considered and its effect on decision making behavior in a risky situation. Dr. K. RAVICHANDRAN (2008) paper titled "A study on Investors Preferences towards various investment avenues in Capital Market with special reference to Derivatives" has conducted a descriptive research where is found that Derivatives acts as a major tool for reducing the risk involved in investing in stock markets for getting the best results out of it. The investors should be aware of the various hedging and speculation strategies, which can be used for reducing their risk. Dr. Gagan Kukreja(2012) paper title Investors "Perception for Stock Market: Evidences from National Capital Region of India" has concluded that investors has to use best technology to analyze and to invest in share market, he also focused on educating investors regarding share market, tools and techniques and other aspects which will yield high return. Dimitrios Maditinos, Zeljko Sevic, Nikolaos Theriou (2014) paper title “Users' perceptions and investment strategies employed in Athen's Stock Exchange" has conducted a research to find the investors perception which includes CFO's, Officers of Athens Stock Exchange, brokers and individual investors, which method they follow to analyze and invest in securities.

In the above mentioned reviews very less work has been conducted on Value based methods to measure the performance of the firm and to invest in securities. I have taken this research to fill the gap which is found in above mentioned research.

\section{RESEARCH QUESTIONS AND HYPOTHESIS}

The hypothesis to be tested are derived from the notion that modern methods like EVA, CAV are the best measure for stock price valuation than traditional measures. Therefore this study poses the following questions.

i. Is there a significance relation between Modern methods and Traditional methods? $\mathrm{HO}$ - There is no significant difference between Modern methods and Traditional methods

H1 - There is a significant difference between Modern methods and Traditional methods

\section{OBJECTIVE OF THE STUDY}

Primary objective of the study is to empirically test the assertion between Modern methods and traditional methods for stock price valuation. Thus the objective of the study is threefold,

I. To find the best among Modern methods and Traditional methods.

II. To examine the relationship between Modern methods and Traditional methods.

III. Different analysis to predict share price.

\section{RESEARCH METHODOLOGY}

\section{DATA COLLECTION AND SAMPLING DESIGN}

In order to survey investors perception related to investor's strategies a questioner was distributed to various investors investing in the company's shares. They were all assumed to have sufficient knowledge of filling questioner. 
The questioner consists of general information on the respondent, investors' perceptions about different analysis used such as fundamental analysis, technical analysis, portfolio analysis or other approaches to value or predict share prices. investors' perceptions about measures used traditional methods, such as EPS, ROI, ROE etc. investors' perceptions about measures used modern methods, such as EVA, EPS, CVA etc. The survey lasted six months. It started mid December 2015 and finished by mid June 2016.

Table 1: Response rate

\begin{tabular}{|l|c|c|c|}
\hline Group & Distributed questioner & Returned questioner & Response rate \\
\hline Shareholders & 200 & 110 & 55 \\
\hline
\end{tabular}

\section{ANALYSIS AND INTERPRETATION}

Table 2: Age of the respondent

\begin{tabular}{|c|c|c|}
\hline Class Interval & No of Respondent & Rate \\
\hline $18-27$ & 65 & 59.09 \\
\hline $28-37$ & 20 & 18.18 \\
\hline $38-47$ & 10 & 09.09 \\
\hline $48-$ above & 15 & 13.63 \\
\hline
\end{tabular}

Analysis : $59.09 \%$ of investors who invest in securities or deals with valuing the firm belongs to the age group between 18-27 and $41.91 \%$ belongs to age group between 28 \& above.

Table 3: Respondent's education

\begin{tabular}{|c|c|c|}
\hline Education & No of Respondent & Rate \\
\hline Higher Education & 05 & 04.54 \\
\hline Diploma & 10 & 09.09 \\
\hline UG & 45 & 40.90 \\
\hline PG & 45 & 40.90 \\
\hline PhD & 05 & 04.54 \\
\hline
\end{tabular}

Analysis : $80.18 \%$ of the respondent are well educated who are either graduate or post graduate and $19.82 \%$ respondent are either diploma holder or with higher education.

Table 4: Monthly income of the Respondent's

\begin{tabular}{|c|c|c|}
\hline Monthly Income & No of Respondent & Rate \\
\hline $5000-10000$ & 08 & 07.27 \\
\hline $10001-20000$ & 12 & 10.90 \\
\hline $20001-30000$ & 40 & 36.36 \\
\hline $30001 \&$ above & 50 & 45.45 \\
\hline
\end{tabular}

Analysis : 90 respondent belongs to the group whose monthly salary is more than $20000 /-$ which comprises of $81.81 \%$ of whole respondent.

Table 5: Experience in the field of investment of Respondent's

\begin{tabular}{|c|c|c|}
\hline Exp. In Years & No of Respondent & Rate \\
\hline $0-5$ & 30 & 27.27 \\
\hline $6-10$ & 10 & 09.09 \\
\hline $11-20$ & 30 & 27.27 \\
\hline 21 and above & 40 & 36.36 \\
\hline
\end{tabular}


Analysis : $63.63 \%$ respondent are having more than 11 years of experience, $09.09 \%$ with more than 6 years and $27.27 \%$ having experience between 0 and 5 years.

Table 6: Respondent's designation in the company

\begin{tabular}{|c|c|c|}
\hline Designation & No of Respondent & Rate \\
\hline Shareholders & 10 & 09.09 \\
\hline Manager & 05 & 04.54 \\
\hline Analyst & 12 & 10.90 \\
\hline Others & 83 & 75.45 \\
\hline
\end{tabular}

Analysis : $\mathbf{2 4 . 5 3 \%}$ respondent are either shareholders or managers or analyst and rest of them belongs to other designations like brokers, lecturer, teachers etc.

Table 7: Methods used for stock price valuation

\begin{tabular}{|l|c|l|}
\hline \multicolumn{1}{|c|}{ Methods } & $\begin{array}{l}\text { No of } \\
\text { Respondent }\end{array}$ & Rate \\
\hline Traditional Method (Like EPS, ROI, ROE etc.) & 98 & 89.09 \\
\hline Modern Method (EVA, CVA, MVA etc.) & 12 & 10.90 \\
\hline
\end{tabular}

Analysis : 89.09\% respondent uses traditional methods like EPS, ROI, ROE for stock price valuation and only $10.90 \%$ used only modern methods like EVA, CVA, MVA etc.

Table 8: Measure used for stock price valuation under Traditional method

\begin{tabular}{|l|c|c|}
\hline \multicolumn{1}{|c|}{ Methods } & No of Respondent & Rate \\
\hline EPS & 60 & 54.54 \\
\hline ROI & 15 & 13.63 \\
\hline ROE & 15 & 13.63 \\
\hline Others & 20 & 18.18 \\
\hline
\end{tabular}

Analysis : In traditional method most of respondent i.e. 54.54\% uses EPS for stock price valuation, $27.29 \%$ uses ROI and ROE and $18.18 \%$ uses other method like NPV , $\mathrm{P} / \mathrm{E}$ ratio etc

Table 9: Measure used for stock price valuation under Modern method

\begin{tabular}{|l|c|c|}
\hline \multicolumn{1}{|c|}{ Methods } & No of Respondent & Rate \\
\hline EVA & 05 & 04.54 \\
\hline CVA & 02 & 01.81 \\
\hline MVA & 01 & 00.90 \\
\hline Others & 102 & 92.82 \\
\hline
\end{tabular}

Analysis : Only 7.25\% of respondent uses only modern measures for stock price valuation and $92.75 \%$ respondent uses either traditional method are combination of both

Table 10: Analysis used to predict the share price or value of the firm

\begin{tabular}{|l|c|c|}
\hline \multicolumn{1}{|c|}{ Methods } & No of Respondent & Rate \\
\hline Fundamental Analysis & 70 & 63.63 \\
\hline Technical Analysis & 20 & 18.18 \\
\hline Portfolio Analysis & 10 & 09.09 \\
\hline Other Approaches & 10 & 09.09 \\
\hline
\end{tabular}

Analysis : 63.63\% respondent uses fundamental analysis where as $36.37 \%$ uses either technical analysis or portfolio and other approaches to predict the share price or value of the firm. 


\section{FINDINGS AND CONCLUSION}

\section{a) FINDINGS :}

$59.09 \%$ of investors who invest in securities or deals with valuing the firm belongs to the age group between $18-27$ and $41.91 \%$ belongs to age group between $28 \&$ above. $80.18 \%$ of the respondent are well educated who are either graduate or post graduate and $19.82 \%$ respondent are either diploma holder or with higher education. 90 respondent belongs to the group whose monthly salary is more than 20000/- which comprises of $81.81 \%$ of whole respondent. $63.63 \%$ respondent are having more than 11 years of experience, $09.09 \%$ with more than 6 years and $27.27 \%$ having experience between 0 and 5 years. $24.53 \%$ respondent are either shareholders or managers or analyst and rest of them belongs to other designations like brokers, lecturer, teachers etc. $\mathbf{8 9 . 0 9 \%}$ respondent uses traditional methods like EPS, ROI, ROE for stock price valuation and only $10.90 \%$ used only modern methods like EVA, CVA, MVA etc. In traditional method most of respondent i.e. 54.54\% uses EPS for stock price valuation, $27.29 \%$ uses ROI and ROE and $18.18 \%$ uses other method like NPV , P/E ratio etc. Only $7.25 \%$ of respondent uses only modern measures for stock price valuation and $92.75 \%$ respondent uses either traditional method are combination of both. $63.63 \%$ respondent uses fundamental analysis where as $36.37 \%$ uses either technical analysis or portfolio and other approaches to predict the share price or value of the firm.

\section{b) CONCLUSION:}

Most of the respondent are not aware of modern methods which can be used more effectively and efficiently to value the stock price and to value the firm. $89.09 \%$ respondent uses traditional method for share price valuation, hence we reject $\mathrm{H} 0$ and accept $\mathrm{H} 1$ i.e There is a significant difference between EVA and Traditional method, respondent prefer to use traditional method rather than modern methods. In traditional method respondent prefer to use EPS for analysis as well as to invest in different securities.

\section{REFERENCES:}

WEB:

1. http://www.investing.com/rates-bonds/india-10-year-bond-yield-advanced-chart

2. http://economictimes.indiatimes.com/markets/stocks/stock-quotes

3. https://in.finance.yahoo.com/q/hp?s=TECHM.NS\&a $=02 \& b=31 \& c=2010 \& d=02 \& e=31 \& f$ $=2014 \& g=d$

4. Stern Stewart and Company, "Why EVA works", http://eva.com/

5. www.investopedia.com/terms/c/cva.asp

6. www.valuebasedmanagement.net/methods cva.html

7. www.ripublication.com/gjfm-spl/gifmv6n2 16.pdf

8. www.iosrjournals.org/iosr-jef/papers/icsc/volume-1/8.pdf

9. http://www.acmeintellects.org/images/AIIIRMSST//an2015/10-1-15.pdf

10. https://www.ici.org/pdf/rpt risk.pdf

\section{JOURNALS:}


1. Malik, Madhu, (2004), "EVA and Traditional Performance Measures: Some Empirical Evidence", The Indian Journal of Commerce, Vol. 57, No. 2, April-June 2004, pp. 32-37.

2. Venkateshwarlu, M. and Nitesh Kumar, (2004), "Value Creation in Indian Enterprises - An Empirical Analysis", The ICFAI Journal of Applied Finance, December 2004, pp. 18-31

3. Copeland, T., Koller, T. \& Murrin, J. (1995). Valuation. Measuring and managing the value of companies. 2nd Edition. New York: John Wiley \& Sons.

4. PETER SCHUSTER, PH.D., AND MEL JAMESON, PH.D. (2012), The Past erformance and Future Value of Companies

(C) 2016 by the authors; licensee Preprints.org, MDPI, Basel, Switzerland. This article is an open access article distributed under the terms and conditions of the Creative Commons by Attribution (CC-BY) license (http://creativecommons.org/licenses/by/4.0/). 
1. Name :

2. Age :
a. $18-27$
b. $28-37$
c. $38-47$
d. 48 and above

3. Education :
i. Higher Education
ii. Diploma
iii. UG
iv. PG
v. PHD

4. Monthly Income:
vi. $5000-10000$
vii. $10001-20000$
viii. $20001-30000$
ix. 30001 and above

5. Experience in the field of Investment(Securities) in years:
a) 0 to 5
b) 6 to 10
c) 11 to 20
d) 21 and above

6. Designation in the company
a. Share holder
b. Manager
c. Analyst
d. other

7. Which method you used for stock price valuation of the firm?
x. Traditional Method (Like EPS, ROI, ROE etc.)
xi. Modern Method (EVA, CVA, MVA etc.)

8. Which measure you use for stock price valuation under traditional method?
a) EPS
b) ROI
c) $\mathrm{ROE}$
d) Other

9. Which measure you use for stock price valuation under Modern method?
a) EVA
b) CVA
c) MVA
d) Other

10. Which analysis is used to predict the share price or value of the firm?
a. Fundamental Analysis
b. Technical analysis
c. Portfolio analysis
d. Other approach. 